\title{
Kemajuan Ekonomi dan Politik Kerajaan Melayu Patani Pada Masa Pemerintahan Raja Ungu (Tahun 1624-1635)
}

Dida Nuraida

\begin{abstract}
Abstrak
Patani memiliki sebuah kerajaan yang berjaya yaitu Kerajaan Melayu Patani, terbentuk di abad ke 16. Sebelumnya kerajaan ini bernama Langkasuka, Kerajaan Langkasuka berada di pedalaman, yang membuat perdagangan dan perniagaan merosot. Dengan hal itu maka Phya Tuk Naqpa atau Sultan Ismail Syah memindahkan ibukota Kerajaan Langkasuka ke pesisir. Ia adalah Raja yang pertama kali memeuluk Islam dan orang yang membuka negeri Patani.

Kerajaan Patani bertambah maju perniagaannya dikarenakan memiliki letak yang strategis dan memiliki alam yang sangat mendukung, pelabuhannya membuat kapal-kapal yang datang terlindungi dari ombak dan angin. Kerajaan Patani mencapai puncak kegemilangannya saat dipimpin oleh raja-raja perempuan, salah satunya adalah Raja Ungu (1624-1635). Ia adalah permaisuri dari Sultan Pahang. Penelitian ini bertujuan untuk menjelaskan bagaimana sejarah kerajaan Patani dan perkembangan Islam di Patani, menguraikan apa saja kemajuan ekonomi dan politik yang dicapai Kerajaan Melayu Patani saat di pimpin oleh Raja Ungu, dapat mengetahui apa saja hal yang menyebabkan kerajaan Patani mengalami kemunduran. Penelitian ini menggunakan metode historis yang bersifat deskriftif analitis. Tahapan yang di tempuh dalam penelitian ini terdapat 4 tahapan, diantaranya: Heuristik (Pengumpulan data), Verifikasi (Kritik Sumber), Interpretasi (Analisis sejarah) dan Historiografi (Penulisan Sejarah).
\end{abstract}

Kata Kunci : Kerajaan Melayu, Patani, Kerajaan Langkasuka, Ekonomi,politik

\begin{abstract}
Farmers have a successful government, namely the Malay Kingdom, formed in the 16th century named Langkasuka Earlier this kingdom, the kingdom of Langkasuka is located in the interior, who make trade and business declined. With it then Phya Tuk Naqpa or Sultan Ismail Shah moved the capital of the Kingdom of Langkasuka to coast. It is the King who first memeuluk Islam and people who open Patani. Patani kingdom prospered because its business has a strategic location and natural features that strongly supports, harbors make ships coming protected from waves and wind. Patani kingdom reached the peak of its glory when, led by the kings daughters, one of whom was King Purple (1624-1635). It is the consort of the Sultan of Pahang.

This study aims to clarify how the history of the kingdom of Patani and the development of Islam in Patani, outlines whatever economic and political progress achieved Malay Kingdom currently led by Raja Ungu, can know what things cause Patani government suffered a setback. This study uses descriptive analysis of historical nature. The step which is taken in this study there are 4 stages, including: Heuristics (data collection), Verification (Source Criticism), interpretation (of history) and historiography (history writing).
\end{abstract}

Keywords : Malay kingdom, farmers, kingdom Langkasuka, economy, politics 


\section{BAB I \\ Pendahuluan}

\section{A. Latar Belakang Masalah}

Letak Patani berada di Thailand Selatan dan secara geografis sangat strategis. Kantong-kantong Muslim yang berada di kawasan Thailand terdapat di propinsi Patani, Yala, Satun, Narathiwat dan Songkhla. Di propinsi tersebut dihuni rata-rata $70-80 \%$ Muslim, selain itu Muslim juga tersebar di beberapa wilayah seperti Pattalung, Krabi dan Nakorn Srithamarrat. Patani merupakan salah satu wilayah di Thailand yang pernah mengukir sejarah besar kegemilangan kejayaaan Islam. Peralihan agama penduduk wilayah Patani diperkirakan terjadi sejak abad $12-15$, salah satu buktinya yaitu ditemukannya batu nisan Muslim bertarikh 1082 dan 1025 di Jawa dan di Campa. ${ }^{1}$

Islam masuk ke Patani diperkirakan sekitar abad ke 10-11 M dibawa oleh pedagang-pedagang Arab seperti dari Yaman, yang sejak zaman Nabi Muhammad telah menjadi tempat persinggahan dagang. Mereka diberi gelar "Khaek" oleh penduduk Asli Thailand yang berarti pendatang atau orang yang datang menumpang. Dalam buku Emanuel Gedinho d'Eredia, Agama Islam masuk lebih dahulu ke Patani dan Pahang daripada ke Malaka.

1 Fatimi 1963:40\&43 dalam Wayne A Bongas. Islamic Cemeteries in Patani (The Malaysian Historical. Kuala Lumpur. 1988) hal 5

2 Dalam buku Taufik Abdullah dijelaskan Khaek adalah sebutan bagi para pedagang arab dan India yang datang dan menetap di Patani, Khaek dalam bahasa Thai berarti pendatang atau tamu, tetapi karena waktu istilah ini mengacu pada tamu asing atau imigran kulit hitam atau lebih populer adalah orang Melayu dan India yang menetap di Muanghtai. Dan dalam konteks ini adalah orang-orang Muslim yang tinggal di Thailand Selatan.
Dalam sejarah Kelantan, sekitar tahun 1150 M, seorang Syeikh dari Patani telah datang ke Kelantan dan menyebarkan agama Islam.

Patani diperintah oleh Raja Phya Tuk Naqpa, orang yang diperkirakan membuka negeri Patani. Raja dikabarkan menderita sakit yang tak kunjung sembuh. Beliau mendengar ada seorang tabib, Syeikh Said Barsisa dari Pasai, seorang Muslim yang mampu menyembuhkan sakitnya. Setelah raja sembuh dari sakitnya, beliau bersama keluarga dan pembesar istana memeluk Agama Islam. Raja Phya Tuk Naqpa berganti nama menjadi Sultan Ismail Shah, dan Sejak saat itu Islam berkembang dan akibatnya pengaruh Hindu-Budha mulai berkurang, lemah dan akhirnya hilang dari Patani.

Setelah berkembangnya Islam di Patani maka Pelabuhan Patani mampu menarik perhatian saudagar-saudagar dari timur seperti Jepang, China, Siam ${ }^{4}$ dan kepulauan Melayu. Pelabuhan Patani mulai ramai sehingga membuat perniagaan bertambah maju dan ekonomi Patani mulai berkembang. Tahun 1511, Malaka jatuh ke tangan Portugis. Sejak itu para pedagang dari Eropa mendatangi Asia Tenggara terutama kepulauan Melayu termasuk Patani. Tahun 1516, Patani menerima

3 Haji Abdul Halim Bashah. Raja Campa dan Dinasti Jembal dalam Patani Besar Patani, Kelantan dan Terengganu. (Pustaka Reka, Kelantan 1994) hal 46-48

4 Siam menunjukkan sekelompok etnis yang merupakan penduduk asli Thailand yang asalusulnya sebagai pendatang dari utara kemudian berbentuklah kerajaan Siam. Dalam Etnis Siam pernah berdiri beberapa kerajaan, seperti Sukhothai, Ayuthya, dan Cholburi (wilayah yang pernah menjadi pusat kerajaan Thailand tersebut, sekarang berubah menjadi propinsi), yang berkuasa di Thailand bagian Utara dan Tengah. Kerajaan-kerajaan tersebut berorientasi Budha. Siam menjadi musuh semenjak Patani menyerang kerajaan Ayuthia 1563, akan di bahas di bab selanjutnya 
kunjungan kapal perniagaan Portugis yang pertama kali dengan seizin sultan, hal ini menandakan awal perniagaan bangsa Eropa di Patani. ${ }^{5}$

Puncak kejayaan Patani saat dipimpin oleh Raja-raja Perempuan, bermula dari Raja Hijau, Raja Biru, Raja Ungu dan Raja Kuning. ${ }^{6}$ Asal mulanya Patani diperintah oleh perempuan karena terjadinya peristiwa pembunuhan yang melibatkan anggota pewaris tahta kerajaan Patani. Saat itu, raja Patani tidak meninggalkan keturunan laki-laki, maka akhirnya perempuan dipilih menjadi raja.

Masa pemerintahan raja perempuan tidak dapat dipandang sebelah mata, terutama dalam bidang ekonomi dan politik, setelah menjalin hubungan dengan Portugis, Siam dan Jepang. Pada masa Pemerintahan raja perempuan, Patani mulai bekerja sama dengan Belanda, Inggris dan Jepang (pada pemerintahan Raja Hijau hubungan diplomatik diresmikan). Abad 17-18, Patani menjadi pelabuhan enterport yang penting bagi perdagangan di negeri sekitar, karena didukung oleh alam pantai yang indah, membuat Patani bertambah ramai dikunjungi.

Keadaan ekonomi dan perdagangan yang baik Patani didukung juga oleh kestabilan politik, terutama pada masa pemerintahan Raja Ungu Patani. Pada masa ini Patani menjadi kekuatan yang tak tergoyahkan, walapun sempat di serang oleh Siam, namun karena didukung oleh alam yang memadai serta sumber daya manuasia yang baik, Patani masih bisa mempertahankan kedaulatannya semenjak terbentuknya kerajaan Patani

5 Ahmad Fathy Al-Fatani. Pengantar Sejarah Patani. (Pustaka Darussalam, Alor Setar) hal 14

6 Selama Penelitian, Penulis tidak dapat menemukan mengapa nama-nama raja perempuan di Patani menggunakan nama-nama warna. pada abad ke-16 hingga akhirnya jatuh ke tangan Siam tahun 1785 . $^{7}$

Raja Ungu naik tahta tahun 1624. Raja Ungu sebagai Permaisuri Pahang, kembali ke Patani setelah suaminya meninggal. Ia dianggap sebagai raja perempuan Patani yang paling handal dan ambisius. Masa pemerintahannya tidak lama. Dalam masa pemerintahannya, Patani mengalami sebuah pertempuran besar dengan Siam dari tahun 1632-1634. Pertahanan kota Patani saat diperintah oleh Raja Ungu sangat unggul karena dibuat benteng di sekelilingnya. Kebesaran Raja Ungu juga tidak dapat terlepas dari pengalamannya yang pernah hidup bersama sultan Pahang. Usia Raja Ungu saat memerintah Patani tidak muda. Hal tersebut menandakan bahwa ia sudah matang dalam menjalankan roda pemerintahan di Patani. Nik Abdul Rakib Bin Nik Hassan ${ }^{8}$ juga mengatakan keberhasilan pemerintahan Raja Ungu tidak terlepas dari sistem pemerintahan Pahang yang di terapkan di Patani yang saat itu juga mulai mengalami kemajuan.

Kenaikan tahta raja perempuan di Patani merupakan sebuah kejadian yang tak terduga. Hal itu akibat dari peristiwa pembunuhan pada pewaris tahta keturunan laki-laki. Namun Patani masih berdiri dan kokoh menjadi sebuah kerajaan yang besar pada zamannya. Zaman yang diperintah oleh raja Perempuan ini terkenal dengan nama "Zaman Ratu-ratu". Pada masa inilah

\footnotetext{
Nik Anwar Nik Mahmud. Sejarah Perjuangan Melayu Patani 1785-1954. ( UKM: Malaysia, 1999) hal 20, lihat juga Ahmad Fathy Al-Fatani. Pengantar Sejarah Patani. (Pustaka Darussalam, Alor Setar) lihat juga Ibrahim Syukri, Sejarah Kerajaan Melayu Patani (UKM: Malaysia, 2002)

8 Kepala bagian Malay Studies di Prince Of Songkhla University, disampaikan pada Stadium General yang diadakan di Fakultas Adab dan Humaniora Universitas Islam Negeri Syarif Hidayatullah Jakarta, 3 Mei 2011.
} 
Patani menikmati zaman keemasannya yang megah dan berjaya. ${ }^{9}$

Bahasan mengenai pemerintahan Patani pada umumnya dan raja perempuan pada khususnya sering kali terabaikan, beberapa literatur lebih banyak menonjolkan integrasi Patani ke dalam pemerintahan Thailand ataupun kebijakan Politik di Patani pada perkembangan Islam di Thailand. Pemerintahan raja perempuan tidak dapat diabaikan, mengingat pada masa tersebut, Patani mendapatkan masa keemasannya.

\section{B. Pembatasan dan Perumusan Masalah}

Pada penulisan skripsi ini, penulis memberikan batasan masalah pada kemajuan-kemajuan yang dicapai oleh pemerintahan Raja Perempuan yaitu Raja Ungu di Kerajaan Melayu Patani dalam bidang politik dan ekonomi. Masa kegemilangan kerajaan Patani saat dipimpin oleh ke empat raja-raja Perempuan yang bermula dari Raja Hijau, Raja Biru, Raja Ungu dan Raja Kuning, dan masa pemerintahannya sering disebut dengan "Zaman Raturatu".

Berdasarkan pembatasan masalah diatas, maka penulis memberikan rumusan pada penulisan ini, yaitu sebagai berikut :

1. Bagaimana sejarah masuknya Islam di Patani?

2. Bagaimana perkembangan Islam masa Raja ungu?

3. Faktor apa Saja yang menyebabkan Raja Ungu Patani mengalami Kemjauan di Bidang ekonomi dan politik?

\footnotetext{
9 Ahmad Fathy Al-Fatani. Pengantar Sejarah Patani. (Pustaka Darussalam, Alor Setar) hal 20
}

\section{Tujuan Penulisan}

Pada penulisan skripsi ini ada beberapa tujuan yang di inginkan dan harus diketahui antara lain:

1. Untuk menjelaskan lebih dalam bagaimana sejarah masuknya Islam di Patani.

2. Untuk menguraikan perkembangan Islam yang terjadi di masa pemerintahan Raja Ungu.

3. Untuk dapat mengetahui apa saja faktor yang menyebabkan kerajaan Patani mengalami kemajuan dalam bidang ekonomi dan politik.

\section{Tinjauan Pustaka}

Beberapa buku seperti karangan Ahmad Fathy Al-Fatani yang berjudul Sejarah Pengantar Patani ${ }^{10}$ adalah buku yang dapat dijadikan referensi, buku ini merupakan terbitan dari Kelantan. Buku tersebut merupakan buku pengantar mengenai Islam di Patani, hingga Patani menjadi sebuah kerajaan yang benarbenar sukses di zamannya. Dalam buku ini juga dijelaskan tentang kerajaan Patani yang dipimpin oleh ratu-ratu atau dalam buku Ahmad Fathy Al-Fatani ini disebut dengan Zaman Ratu-ratu. Periode masa pemerintahan ratu-ratu ini berlangsung selama kurang lebih satu abad sebelum raja perempuan yang terakhir yaitu Raja Kuning meninggal dunia. ${ }^{11}$ Dalam masa pemerintahan raturatu inilah Patani mengalami masa keemasannya yang sangat megah dan berjaya di Asia Tenggara yang hampir menyamai Aceh di Nusantara dan di sini juga di angkat bahwa peran masuknya Islam ke Patani tidak terlepas dari peran Kerajaan Samudra Pasai. ${ }^{12}$

\footnotetext{
10 Ahmad Fathy Al-Fatani. Pengantar Sejarah Patani. (Pustaka Darussalam, Alor Setar)

${ }^{11}$ Ibid 24

${ }^{12}$ Ibid 13
} 
Buku Patani dalam Tamadun Melayu karya dari Mohd Zamberi A. Malek $^{13}$ adalah buku yang membahas mengenai Patani. Mulai dari sejarah Kerajaan Patani sampai Patani saat ini. Buku ini sangat lengkap menjelaskan tentang Patani termasuk hal yang sangat detail seperti adat, kepercayaan, ulamaulama Patani. Buku ini memang secara khusus tidak menjelaskan pemerintahan raja perempuan dalam satu bab melainkan membagi-bagi bab berdasarkan keseluruhan atau tematik seperti Patani sebagai lambang kegemilangan dan Patani sebagai pusat pengkajian Islam Nusantara. Bab yang disajikan buku tidak dalam metode kronologi berdasarkan urutan waktu terjadinya peristiwa.

Sajian yang memberikan tentang tema sejarah Patani dan Pemerintahan raja perempuan terdapat dalam buku Umat Islam Patani Sejarah dan Politik, masih karangan Mohd. Zamberi A. Malek. $^{14}$ Tidak seperti buku yang sebelumnya, dalam buku ini Malek lebih menguraikan isi buku dalam metode kronologi berdasarkan urutan waktu terjadinya peristiwa, mulai dari Patani Pra Islam, Patani mendapatkan nama, Patani dipimpin oleh raja dan raja perempuan keturunan Dinasti Seri Wangsa, masa Kejatuhan Patani dan Patani hingga saat ini. Kajian raja perempuan dalam buku ini dimuat per bab yang memudahkan dalam penelitian, tetapi pada bahasan mengenai Raja Ungu buku ini hanya mengulas keadaan Politik masa pemerintahan Raja Ungu, tetapi dalam bab -bab yang lainnya bisa

13 Mohd Zamberi A. Malek. Patani Dalam Tamadun Melayu ( Dewan Bahsa dan Pustaka, 1994, Kualalumpur)

${ }^{14}$ Mohd Zamberi A. Malek .Umat Islam Patani Sejarah dan Politik (Hizbi Shah Alam: Kelantan, 1993) dijadikan sebagai salah satu referensi utama $^{15}$

\section{E. Metode Penelitian}

Metode yang akan digunakan didalam penyusunan skripsi ini adalah metode historis dan bersifat deskriftif analitis. Metode historis adalah proses menguji dan menganalisa secara kritis rekaman dan peninggalan masa lampau $^{16}$. Dengan menggunakan metode ini diharapkan dapat membantu untuk mengetahui fakta dan sejarah pada masa lampau. Adapun dalam melakukan penelitian ini penulis menggunakan metode historis yang meliputi 4 tahapan $^{17}$, yaitu:

A. Heuristik

Heuristik adalah kegiatan untuk mencari data atau pengumpulan bahanbahan atau sumber sejarah. Hal ini merupakan tahap awal yang harus dilakukan seorang peneliti. Adapun dalam pengumpulan data-data dan sumber yang akan digunakan dalam membuat skripsi ini penulis menggunakan metode library research, penulis mencari buku-buku di perpustakaan yang berhubungan dengan judul. Jika menurut Mustika Zed dalam bukunya Studi Kepustakaan ada beberapa langkah dalam penelitian yang menggunakan studi kepustakaan di antaranya, menyiapkan alat perengkapan, menyiapkan bibliografi kerja, mengorganisasikan waktu, membaca dan mencatat bahan penelitian.

Sumber yang digunakan tidak hanya berasal dari buku melainkan juga berupa surat kabar, majalah serta artikelartikel yang diperoleh dari internet. Sumber-sumber tertulis tersebut ditemukan di Perpustakaan utama UIN

\footnotetext{
${ }^{15}$ Ibid hal 13

${ }^{16}$ Louis Gottschalk. Mengerti Sejarah. (UI Pers: Jakarta 1975) hal 32

17 Dudung Abdurahman. Metode Penelitian Sejarah.( Logos: Jakarta. 1999) hal 54
} 
Syarif Hidayatullah Jakarta, Perpustakaan Fakultas Adab dan Humaniora, Perpustakaaan Nasional RI, Perpustakaan FIB UI, Perpustakaan Iman Jama Lebak Bulus, dan milik pribadi Mahasiswa Patani di Ciputat dan Jogyakarta, juga mengunjungi Ipmiti di Jogyakarta, selain buku-buku dari perpustakaan-perpustakaan penulis juga mendownlod buku dari Internet.

\section{B. Verifikasi}

Setelah melakukan heuristik atau pengumpulan sumber-sumber maka tahap selanjutnya yang harus dilakukan adalah kritik sumber. Kritik sumber adalah usaha untuk mendapatkan sumber-sumber yang relevan dangan cerita sejarah yang ingin disusun sesuai dengan judul. Setelah mencari sumbersumber dari perpustakan yang telah disebutkan, penulis akan melakukan verifikasi.

\section{Interpretasi}

Interpretasi atau penafsiran sejarah seringkali disebut juga dengan analisis sejarah. Tujuannya agar data yang ada mampu untuk mengungkap permasalahan yang ada, sehingga diperoleh pemecahannya. Dalam hal ini penulis akan melihat fakta satu sama lain yang telah ditemukan dari hasil heuristik dan verfikasi. Dalam hal tersebut, penulis akan menjelaskan masalah Kerajaan Patani kemudian kemajuan ekonomi dan politik yang dicapai Kerajaan Patani saat dipimpin oleh Raja Ungu. Dalam usaha menafsirkan faktafakta yang ada dilakukan beberapa hal sebagai berikut: (1) diseleksi, disusun, (3) diberikan tekanan, (4) ditempatkan dalam urutan yang kausal. ${ }^{18}$

\section{Historiografi}

Historiografi adalah sejarah penulisan sejarah, tahap ini adalah tahap

\footnotetext{
${ }^{18}$ Louis Gottschalk. Mengerti Sejarah. hal 20
}

yang terakhir dalam menulis skripsi ini. Setelah melakukan tahap heuristik, verifikasi dan interpretasi, selanjutnya historiografi dengan menulis dalam suatu urutan yang sistematik yang telah diatur dalam pedoman penulisan skripsi. Dalam penulisan ini penulis berusaha menyusun cerita sejarah menurut urutan peristiwa, berdasarkan kronologi waktu dan tema-tema tertentu yang akhirnya isi inti dari skripsi atau klimaks dari skripsi ini.

\section{II.PEMBAHASAN}

\section{SEJARAH PERKEMBANGAN ISLAM DI PATANI (MASA RAJA UNGU PATANI 1624-1635)}

\section{Sejarah Awal Patani}

Patani merupakan wilayah yang berada di bagian selatan Thailand, wilayah yang didominasi oleh etnis Melayu Islam. Wilayah Thailand bagian selatan yang banyak dihuni oleh umat Islam ini berjumlah 2,3 juta atau sekitar $4 \%$ dari seluruh penduduk Thailand. ${ }^{19}$ Menurut Chiwat Sathanand ${ }^{20}$, populasi muslim di Thailand di atas 10\%, dengan analisa bahwa perkiraan jumlah masjid di Patani sebanyak 3113 dan perkiraan jumlah rumah sekitar 183 dan masing-

${ }^{19}$ Laporan sensus tahun 2007 yang dilakukan oleh Kantor Survei Thailand atau NTSO menunjukkan bahwa ada sekitar 2 juta orang yang tinggal di provinsi Patani, Yala, Narathiwat, Satun dan Songkhla. Satu juta Muslim mendiami provinsi-provinsi tengahselatan dekat Nakorn Sri Thammarat. Satu juta Muslim orang tinggal di daerah Bangkok di Thailand pusat. Mereka memiliki daerah tempat tinggal untuk waktu yang sangat lama dan mereka tidak pernah berasimilasi ke Thailand moderen. Dalam buku Howard federspiel, Sulthan, Shamas and Saints.

${ }^{20}$ Changwad adalah sebutan Wilayah adalah istilah Siam, atau disini lebih dikenal dengan istilah provinsi 
masing dengan 8 orang anggota maka sejumlah 4,5 juta atau 7,3 persen dari total populasi di empat provinsi selatan sekitar 70 persen dari penduduk Melayu Muslim. ${ }^{21}$

Wilayah di selatan Thailand yang banyak dihuni umat Islam meliputi Patani, Yala, Narathiwat, dan Satun. Mereka memiliki budaya tersendiri jika dibandingkan dengan penduduk Thailand di wilayah lain yang mayoritas beragama Budha. $^{22}$

Awalnya Patani dikenal dengan nama Langkasuka ${ }^{23}$, namun masih

21 Jon Fuston, Artikel Thailand dalam Voices of Islam in Southeast Asia: A contemporary Sourcesbook Ed, Greg Fedly dan Virginia Matheson Hooker. Institute Of Southeast Asian Studies. 2006. Hal 77

22 Skripsi Gerakan Muslim Melayu Tahiland Selatan 1973-1980 M ( Gerakan Minoritas Melawan Mayoritas) dalam Faculty of Law, Thailand and the Islamic World (Bangkok: Chulalongkorn University, tt.), hlm. 7.

${ }^{23}$ Langkasuka adalah Kerajaan yang dipercayai sebagai kerajaan Patani, Langkasuka juga dikenali sebagai Lang-ya-shiu, Lang-chia-shu (China), Langasyuka (Arab) dan Ilangasoka (inkripsi Tangore) yang terletak di kawasan yang dikenali sebagai Patani (dahulunya Kedah). Langkasuka adalah kerajaan Hindu Melayu Siam yang terletak di Semenanjung Malaysia. Kerajaan ini bersama dengan Kerajaan Kedah Tua mungkin merupakan kerajaan yang paling awal di Tanah Melayu. Menurut satu sumber, kerajaan ini muncul pada kurun ke-2 masehi. Legenda orang Melayu mempercayai bahwa Langkasuka terletak di Kedah, dan kemudian berpindah ke Patani. Dipercayai bahawa Langkawi berasal dari perkataan Langkasuka. Sumber-sumber sejarah tidak banyak tetapi berdasarkan satu rekaman sejarah Dinasti Liang China (500 M) merujuk kerajaan itu sebagai "Langgasu" yang muncul pada kurun pertama masehi. Nama Langkasuka juga ada disebut dalam tulisan-tulisan Melayu dan Jawa, sementara tulisan-tulisan dari China pernah menyebut sebuah negeri yaitu Lang-ya-hsiu atau Lang-chia-shu. Pada tahun 515 M Raja Bhagadatta menjalinkan hubungan dengan China. Hubungan itu dikuatkan lagi dengan utusan-utusan yang datang pada tahun 523, 531 dan 568 masehi. Pada kurun ke-12, Langkasuka merupakan negeri di bawah naungan kerajaan banyak perdebatan sarjana-sarjana mengenai letak negara Langkasuka. Hikayat Merong Mahawangsa mengatakan Kerajaan Langkasuka terbagi atas dua bagian, terletak di kawasan tebing Sungai Merbok dan terletak di pantai laut China selatan. ${ }^{24}$

Istilah Patani sendiri mengundang keingintahuan mengenai mengapa nama Langkasuka berubah menjadi Patani. Beberapa teori muncul seiring dengan penyebutan istilah Patani. Menurut Hikayat Patani karya A. Teeuw dan Wyat, negeri Patani berasal dari kata Pak Tani. Dalam Hikayat tersebut diceritakan bahwa Phya Tuk Naqpa anak dari Phya Tub Kerub Mahajana keturunan dari raja Langkasuka yang memerintah kota Mahligai ${ }^{25}$. Letak kota Mahligai yang berada di pedalaman menyebabkan Phya Tuk Naqpa berinisiatif untuk memindahkan ibukota kerajaan lebih ke pesisir. Hal ini berpengaruh terhadap sektor perdagangan yang menyebabkan sulitnya para saudagar dari wilayah luar Patani untuk bertransaksi jual beli jika pusat kota berada di pedalaman sehingga perdagangan dan perniagaan kerajaan merosot. Dan Phya Tuk Naqpa melihat keadaan yang cukup memungkinkan untuk memindahkan Ibu Kota, maka Phya Tuk Naqpa memerintahkan negerinya pindah ke pesisir dan menyebut negeri itu sebagai Pak Tani, namun lama-kelamaan karena faktor penyebutan maka disebutlah Patani. Pantai yang ditemukan oleh Phya Tuk Naqpa adalah pantai yang indah,

Srivijaya dan pada kurun ke-15, kerajaan Sriwijaya digantikan dengan Kerajaan Patani.

24 Hikayat Merong Mahawangsa mengatakan Patani berada di pantai barat berlainan dengan pendapat lain yang mengatakan berada di pantai Timur. Hikayat Merong Mahawangsa dalam buku Haji Abdul Halim Bashah , Raja Campa dan Dinasti Jembal Dalam Patani Besar, Patani Kelentan, Terengganu.

${ }^{25}$ Ibukota Kerajaan Langkasuka 
tanahnya datar, tinggi dan bebas banjir. selain itu, terdapat sungai yang menghubungkannya ke darat. ${ }^{26}$

Cerita Bahari orang Patani juga memiliki pendapat yang berbeda tentang asal-muasal kata Patani, kata Patani berasal dari kata "Pantai ini". Pendapat tersebut menceritakan bahwa serombongan Raja dan para pengikutnya pergi berburu. Saat berburu rombongan menemukan Kijang yang tersesat di hutan, Kijang yang diburu itu lari menuju pantai dan menghilang di sana. Beberapa lama kemudian, raja memutuskan berburu lagi dan menanyakan kemana larinya Kijang tersebut, rombongan mengatakan bahwa Kijang berlari ke arah Pantai ini. Lamakelamaan sebutan pantai ini berubah menjadi Patani.

Setelah pusat pemerintahan dipindahkan, Patani banyak dikunjungi dan semakin padat penduduknya, Patani dijadikan tempat yang layak untuk sebuah pemerintahan. Dinasti Seri Wangsa $^{27}$ yang memerintah saat itu mendirikan sebuah Istana dalam kota Geresik, yang berdekatan dengan Sungai Panyeri.

\section{Masuknya Islam di Patani}

Teori masuknya Islam di Asia Tenggara umumnya dan Patani khususnya memang masih diperdebatkan. Beberapa hal cenderung terhadap satu teori namun, data yang mendukung teori tersebut masih kurang. ${ }^{28}$ Islam di Patani mulai ada sejak abad ke 10-11 M, tetapi Islam di Patani baru

\footnotetext{
26 Ahmad Fathy Al-Fatani. Sejarah Pengantar Patani.

${ }^{27}$ Dinasti seri Wangsa adalah keturunan dari Raja Langkasuka dan orang yang pertama kali membuka negeri Patani, Dinasti Seri wangsa memerintah di Patani hanya sampai Raja Kuning (1635-1688)

28 Azyumardi Azra, Jaringan Ulama Timur Tengah dan Kepulauan Nusantara abad XVII\&XVIII. ( Kencana, 2008, Jakarta) hal 2
}

kokoh berkembang sekitar abad ke 15-16 M. Sama seperti yang membawa agama Islam di Nusantara, agama Islam yang masuk Patani juga dibawa oleh para kaum Pedagang. Para Pedagang tersebut menetap di Patani dan mereka diberi gelar Khaek oleh orang-orang Siam. Menurut Buku Emanuel Gedinho d'Eredia yang di tulis tahun 1613 agama Islam masuk ke Patani lebih dulu dibanding ke Malaka, hanya saja perkembangan Islam lebih cepat di Malaka dibanding di Patani karena raja Patani yang saat itu memerintah belum memeluk Islam. Kekuatan Islam di Asia tenggara dan termasuk Patani merupakan sebuah identitas dan kesatuan yang kuat dalam satu sistem agama Islam. Penyebaran Islam yang terjadi di abad ke-16 semakin meningkat, sehingga kekuatan Asia Tenggara selain melawan penjajahan juga berjuang dalam membawa identitas agama Islam, budaya dan adat. ${ }^{29}$

Bukti lain yang menguatkan bahwa Patani merupakan kerajaan yang berubah menjadi corak Islam adalah ditemukannya batu nisan Raja Islam pertama Patani yang bentuknya sama dengan batu nisan Raja Pasai yang pertama kali memeluk Islam, Sultan Malik As-Shaleh yang bertarikh 1297 M. Hal ini membuktikan telah terjadi hubungan antara Patani dan Kerajaan Samudra Pasai.

Hamka mengatakan Islam pada masa Langkasuka sudah mulai ramai dengan saudagar Islam yang berdakwah bagi masyarakat setempat. Hal tersebut juga terkait dengan penemuan prasasti Pathalung yang mengatakan Islam berasal dari Campa pada abad ke 11-12 M. Bukti-bukti paling awal permulaan Islam di semenanjung tanah Melayu dapat ditemukan pada prasasti di sungai

29 Howard Federspiel. Sulthans, Shamans dan Saints: Islam and Muslims in Southeast Asia. (University of Hawai'i Press: USA). Hal 38 
Tersat Trengganu. Menurut Syekh Naguib Al - Attas bahwa mengenai tahun penulisan di prasasti tersebut ialah pada hari Jum'at 4 Rajab $702 \mathrm{H}$ bersamaan dengan 22 Februari 1303 M. ${ }^{30}$ Sementara di Kelantan, menurut Sa'ad khri (1974) dalam sejarah Kelantan bahwa ditemukan sekeping uang dinar emas pada tahun 1914 M, di satu sisi kepingan tersebut tertulis kalimat "Al-Julus Kelantan", dan angka arab "ovv" yang berarti "menduduki tahta Kelantan tahun 577" dan di sisi lain tertulis pula kata "Al-Mutawakkil" yang artinya "yang bertawakkal", yaitu gelaran bagi pemerintah. Sedangkan angka 577 merupakan tahun Hijriah yang bersamaan dengan tahun $1181 \mathrm{M}$. Hal tersebut membuktikan bahwa dalam abad ke-12 telah berdiri sebuah kerajaan Islam di Kelantan, daerah Pantai Timur semenanjung Malaya.

\section{Perkembangan Islam di Patani Pada Masa Raja Ungu}

Islam di Patani telah lama ada yaitu sekitar Abad ke 10-11 M. Namun, perkembangan pesatnya baru terjadi di sekitar abad ke 16 dan dapat dikatakan setelah kejatuhan Malaka ke tangan Portugis Tahun 1511 M. Meskipun demikian, kegiatan lain yang berbau Bid'ah dan kufarat masih dilakukan, sebutan Sinkretisme masih melekat. ${ }^{31}$ Menurut Hikayat Patani, Syeikh Said yang meng-Islamkan raja Patani juga ditugaskan untuk mengajarkan Islam di sana. Kedatangan Islam membawa banyak perubahan dalam aspek pemikiran, kebudayaan bahasa, pendidikan, dan politik. ${ }^{32}$.

\footnotetext{
${ }^{30}$ Wikipedia.com / sejarah Islam di Thailand. com

${ }^{31}$ Haji Abdul Halim Bahsah ( Abhar), Raja Campa dan Dinasti Jembal dalam Patani Besar Patani, Kelantan dan Terengganu.47-52

32 Mohd Zamberi A. Malek. Patani dalam Tamadun Melayu ( Dewan Bahsa dan Pustaka, 1994, Kualalumpur) hal 13-14
}

Selain mengembangkan Islam dalam negeri, Patani juga mengembangkan Islam ke berbagai wilayah, Patani mengutus orang-orang nya untuk menyebarkan Islam di luar Patani, ke Campa maupun Nusantara. Meneruskan langkah penyebaran Islam, ulama dari Patani dikirim ke berbagai wilayah di Nusantara maupun Semenanjung.

Dalam hal kesustraan di Patani mulai berkembang tulisan Jawi yang semakin luas. Sistem pondokan mulai diperkenalkan di Patani, di antara pondok di Patani yang terkenal adalah Pondok Dala, Dermin, Semela, Dual, Kota, Geresik, Teluk Manak. Pelajarpelajar yang datang tidak hanya dari negeri Patani sendiri tetapi juga dari negeri-negeri lain. Perkembangan bahasa Melayu juga mulai berkembang dan digunakan dalam kehidupan sehari-hari, misalnya khutbah disampaikan dengan bahasa Melayu.

Pondok-pondok di Patani biasanya terdapat di pedalaman karena merupakan bentuk pengasingan diri dari pengaruh luar agar pelajaran Islam benar-benar meresap. Wan Husein yang pertama kali mendirikan Pondok di Patani, adalah hafidz Al-Quran yang berasal dari kampung Sena dan berpindah ke Pekbun. Wan Husein pernah ke Jawa dan belajar Islam di sana. Jika di Jawa, Maulana Malik Ibrahim yang memperkenalkan pondok, sedangkan di Patani diperkenalkan oleh Wan husein. Di samping itu Wan Husein juga mendirikan masjid Teluk Manak. ${ }^{33}$

Identitas Melayu Muslim Patani yang paling signifikan adalah peradaban manuskrip atau naskah-naskah Melayu dalam tulisan Jawi. Tulisan Jawi adalah yang paling sesuai dengan masyarakat

\footnotetext{
${ }^{33}$ Haji Abdul Halim Bahsah ( Abhar), Raja Campa dan Dinasti Jembal dalam Patani Besar Patani, Kelantan dan Terengganu hal 67-69. Lihat juga lampiran 6
} 
Melayu Islam di Patani. Penggunaan bahasa Melayu di Patani memiliki sejarah yang panjang, bermula pada kerajaan Langkasuka yang disebutkan oleh Negarakertagama tahun 1635 bahwa Langkasuka berada di bawah naungan kerajaan Sriwijaya dan Majapahit. Hal ini menandakan bahwa Patani menggunakan adat dan bahasa Melayu. $^{34}$

\section{A. Saluran Islamisasi Masa Raja Ungu Melalui Perdagangan}

Sekitar abad 15, Islam telah kokoh menjadi agama resmi di Patani. Seiring perjalanan waktu, Islam telah menyebar ke seluruh Semenanjung Malaya. Kekuatan Islam di Semenanjug juga tidak dapat terlepas dari faktor ekonomi masyarakat yang cukup baik sehingga memudahkan Islam berkembang dengan luas. Hal ini didukung oleh alam wilayah Patani yang sangat baik, wilayah yang stategis.

Patani menjadi pelabuhan yang penting sejak zaman kerajaan Langkasuka, kerajaan Langkasuka saat itu menguasai jalur perdagangan timurbarat melalui Segenting Kra dan kekuasaannya meliputi kawasan Semenanjung Malaya hingga Teluk Benggala. ${ }^{35}$ Saat dibawah pemerintahan Sriwijaya, Patani mulai menapaki kemajuan, ramai dan terkenal. Hasil negeri Patani pada waktu itu banyak berupa pertanian dan perniagaan. Beberapa pengetahuan bernilai seperti teknik membajak dan berdagang diterima oleh orang Patani dari orang Jawa. Besarnya upeti yang diberikan setiap tahun kepada kerajaan Sriwijaya

34 Howard Federspiel. Sulthans, Shamans dan Saints: Islam and Muslims in Southeast Asia. Dalam skripsi Proses Integrasi Patani ke Teoriti Thailand.

${ }^{35}$ Nik Anwar nik Mahmud. Sejarah Perjuangan Melayu Patani 1785-1954 (University Kebangsaan Malaysia. 1999) Hal 15 menunjukkan bahwa Patani ketika itu kaya dan makmur.

Dalam buku Umat Islam Patani Sejarah dan Politik karya Mohd Zamberi A. Malek, teluk Patani berbentuk tanjung dan terdapat sebidang tanah sempit yang panjangnya kira-kira tujuh hingga delapan kilometer yang terhubung dengan tanah besar, arah bagian timur-barat membengkok seperti tanduk yang akan memberikan perlindungan terhadap kapal-kapal yang berlabuh. $^{36}$ Oleh karena itu, para pedagang yang datang membawa kapal tidak khawatir kapalnya yang akan terkena ombak atau hempasan angin karena pelabuhan terlindungi. Selanjutnya bukti pelabuhan Patani ramai dan dikunjungi adalah tulisantulisan pelawat asing yang datang ke Patani seperti Van Neck, Nicholas Gervaise, Alexander Hamilton, John Smith, Joost Schouten, John Nieuhoft dan Godinho de Eredia. Salah satunya adalah tulisan dari Van Neck yang berisi:

....She Has reigned verry peacefully together with her Councillors (Whon they call mentery) for about 13 or 15 so that all her subject are better pleased with her rule than that of the deseased king, as all food stuffs are at present very cheap there, which during the kings time were hall all exspensive again ( so they say) as a result of the heavy exactions which were made than.... ${ }^{37}$

Patani muncul sebagai pusat perdagangan yang penting setelah jatuhnya Malaka ke tangan Portugis tahun 1511. Hal pertama yang dilakukan

\footnotetext{
${ }^{36}$ Mohd Zamberi A Malek. Umat Islam Patani Sejarah dan Politik . hal 33

37 Mohd Zamberi Malek. Umat Islam Patani Sejarah dan Politik
} 
Portugis adalah mengadakan hubungan dengan seluruh negeri di Nusantara dan Semenanjung, Patani juga telah di datangi oleh orang-orang Portugis. ${ }^{38}$ Patani menjadi tempat aktivitas perdagangan bagi Portugis dan juga bagi negeri-negeri lain. Patani menjadi pusat perdagangan di Asia Tenggara.

Dalam buku Mohd Zamberi A Malek Patani dalam Tamadun Melayu disebutkan beberapa faktor penting mengapa Pelabuhan Patani begitu berperan penting, diantaranya ${ }^{39}$ :

1. Peranan kerajaan Melayu Langkasuka pada zaman dahulu sebagai pelabuhan penting dipercayai berada di lokasi yang sama.

2. Dilihat dari posisinya, pelabuhan Patani sangat strategi.

3. Pelabuhan Patani sebagai tempat yang cocok dalam singgahan kapal-kapal jika terdapat angin muson timur laut.

4. Sumber daya alam yang mencukupi seperti rempahrempah.

5. Tempat pertemuan antara pedagang Barat, Cina, Jepang dan Tanah Melayu..

6. Kestabilan politik dan pemerintahan Patani serta kemudahan seperti sistem cukai, dan keperluan-keperluan lain.

Masih dalam buku A. Malek, semenanjung Malaya disebut sebagai semenanjung emas, yaitu wilayah Patani hingga Pahang. Patani terkenal dengan penghasil emas, penghasil biji timah, biji besi, bauksit. ${ }^{40}$ Saat Patani di bawah pengaruh Siam, Patani diharuskan mengirim upeti. Upeti yang diberikan Kerajaan Patani kepada Kerajaan Siam berupa bunga emas, atau upeti berbentuk

\footnotetext{
${ }^{38}$ Ibid hal 34

${ }^{39}$ Ibid hal 20

${ }^{40}$ Lihat Lampiran 7
}

pohon yang terbuat dari Emas dan perak. ${ }^{41}$ Upeti diberikan oleh Patani bernilai $£$ 1000 setiap tiga tahun sekali. Siam menganggap bahwa pengiriman upeti ini sebagai tanda bahwa negeri yang bersangkutan takluk di bawah naungan Siam, tetapi negeri-negeri yang lain seperti juga Patani menganggap bahwa pengiriman upeti sebagai tanda persahabatan diplomatik.

Raja perempuan lainnya yang berjaya ialah Raja Hijau $^{42}$ banyak membawa perkembangan bagi Patani, untuk urusan perdagangan luar negeri. Pada masa pemerintahannya, banyak negara-negara Eropa yang datang mengunjungi Patani untuk mengadu nasib. Patani telah menjalin hubungan dengan Portugis pada masa Sultan Ismail Syah. Pada masa Ratu Hijau dibangun hubungan diplomatik dengan Belanda, Inggris dan Jepang. Hal ini disebabkan Portugis yang memberlakukan sistem cukai yang begitu tinggi di Malaka sehingga banyak para pedagang yang pindah ke Patani. Dalam urusan dalam negeri, Raja Hijau menjalankan proyek menggali terusan dari Keresiek hingga ke Pangkalan Tembangan untuk kemudahan lalu lintas juga untuk persediaan air minum. ${ }^{43}$

Setelah Raja Hijau Meninggal dunia, Raja Biru adik dari Raja Hijau naik tahta, ia telah mengadakan pembangunan terhadap terusan tambangan yang sering membanjiri dan

${ }^{41}$ DGE Hall. Sejarah Asia Tenggara. Hal 32-33 juga dalam Haji Abdur Rahman Dawud Sejarah Negara Pattani Darusalam terbitan Patani.

42 Dalam sejarahnya, Perempuan memerintah adalah hal yang paling baru di Semenanjung Malaya, dia adalah Raja Hijau perempuan yang pertama kali menjadi Raja, Raja Hijau adalah anak perempuan dari Sultan Mansur Syah yang menaiki tahta pada tahun 1584, lebih jelasnya pada subab selanjutnya.

${ }^{43}$ Haji Abdul Halim Bashah. Raja Campa dan Dinasti besar dalam Patani Besar, Patani, Kelantan dan Terengganu hal 87 
meruntuhkan tebing, dan juga membuat air di sungai Keresiek menjadi tawar sehingga membuat pedagang garam merugi. Pada masa Raja Hijau banyaknya para pedagang dari negara Eropa membuat persaingan perdagangan semakin meningkat, terutama antara Inggris dan Belanda.

Para pedagang Jepang pada masa pemerintahan Raja Hijau juga telah melakukan hubungan, walaupun sebelumnya mereka telah berniaga di Patani namun baru pada masa pemerintahan Raja Hijau Jepang mengadakan hubungan yang resmi.

Hubungan dengan Siam pun cukup baik, banyak pedagang Siam yang berniaga di Patani, dan orang-orang Patani yang datang ke Siam. Hal tersebut juga dilakukan dengan mengantar masingmasing utusan ke Patani dan Siam. ${ }^{45}$

Tahun 1602, Belanda tiba di Patani dalam mengadakan perjanjian perdagangan. Portugis yang telah ada di Patani sebelum Belanda merasa terusik dengan kedatangan orang-orang Belanda.Keadaan ini bertambah dengan persaingan di Malaka antara Belanda dan Portugis. $^{46}$ Kegiatan perdagangan Belanda di Patani terus meningkat, hal tersebut menyebabkan persaingan menjadi kuat, Selain di Patani, $V O C^{47}$ Belanda juga mendirikan loji-loji di Brunei, Ayuthia. Persaingan dagang antara Portugis dan Belanda sudah merambat kepada perampasan kapal atau

\footnotetext{
44 Ibrahim Syukri. Sejarah Kerajaam Melayu Patai. hal 41

${ }^{45}$ Ibid hal 41

46 Mohd Zamberi A Malek. Patani dalam Tamadun Melayu. Hal 22-23

47 VOC adalah singkatan dari Veerenigde Oost Indische compaigne, merupakan serikat dagang milik Belanda yang berada di Asia Tenggara, didirikan pada tahun 1602. Jika di Indonesia (Batavia) pada awalnya VOC hanya merupakan Serikat dagang namun lama kelamaan memonopoli perdagangan dan menjajah sebagian wilayah Indonesia khususnya pulau Jawa.
}

penyerangan kapal, hal ini dilakukan oleh kapal Magalane dan Fayeth milik Portugis menyerang kapal Der gaude milik Belanda. ${ }^{48}$ Selain berniaga dengan Portugis dan Belanda, Patani mendapat kunjungan dari Inggris pada tahun 1611 yang menambah kesibukan pelabuhan Patani. ${ }^{49}$

Selain bermusuhan dengan Portugis, Belanda juga bersaing dengan Inggris, perampasan kapal terjadi pada tahun 1618 ketika Inggris menawan kapal milik Belanda dari Patani menuju Banten, tindakan serupa juga dilakukan oleh Belanda ketika kapal Inggris bernama Hound and Sampson tiba di Patani dan berakibat pada pembunuhan salah satu awaknya, John Jourdain. Persaingan antara Belanda dan Inggris telah dipulihkan dalam perjanjian Antwerp $^{50}$ tahun 1619. Tetapi perdagangan Belanda dan Inggris di Patani tidak bertahan lama, rempahrempah yang diekspor ke Eropa tidak lagi banyak peminat, maka Jan Pieter Zoon Coen ${ }^{51}$ akan menutup loji-loji yang kurang menguntungkan. Tahun 1623, loji di Patani resmi ditutup. Begitu juga dengan Inggris mengikuti langkah Belanda menutup lojinya di Patani. ${ }^{52}$

48 Mohd Zamberi A Malek. Umat Islam Patani Sejarah dan Politik. hal 52

49 Patani adalah negeri Melayu pertama yang dikunjungi oleh Inggris, hal ini di sambut baik oleh Raja Hijau, perundingan pun dilakukan dalam menetapkan harga-harga barang dan cukai pelabuhan.Mohd Zamberi A Malek. Umat Islam Patani Sejarah dan Politik. hal 92

${ }^{50}$ Perjanjian Antwerp adalah perjnjian yang terjadi antara Belanda dan Inggris terkait masalah perdagangan di Asia Tenggara, hasil dari perjanjian Antwerp adalah kedua syarikat dagang Belanda dan Inggris tetap berhubungan baik dalam perdagangan rempah-rempah di Kepulauan Nusantara Melayu. Dalam buku Mohd Zamberi A Malek. Umat Islam Patani Sejarah dan Politik. Hal 63

${ }^{51}$ Jan Pieter Zoon Coen adalah Gubernur jandral VOC

52 Mohd Zamberi A Malek. Umat Islam Patani Sejarah dan Politik hal 52-64 
Setelah wafatnya Raja Biru, maka yang dilantik menjadi raja Patani adalah Raja Ungu. Raja ungu adalah permaisuri Sultan Abdul Ghofur dari Pahang $^{53}$, ia telah lama tidak tinggal di Patani tetapi pada masa pemerintahan Raja Hijau, Raja Ungu dijemput untuk kembali tinggal di Patani. Raja Ungu menaiki tahta pada tahun 1624 dan memakai gelaran Paduka Syah Alam, Raja Ungu menolak gelaran yang diberikan Siam yaitu Phra Nang Cao Yang $^{54}$ atau Raja Nan Cayang. Pada masa pemerintahannya Raja Ungu sangat memusuhi Siam dan menolak memberikan upeti seperti para pendahulunya. $^{55}$

Kemajuan Patani bergantung pada sistem pelabuhan bebas, setiap kapal-kapal yang datang dari Eropa, Asia barat, India maupun China dikenakan bayaran cukai impor sebanyak $6 \%$ dan $1 \%$ oleh perbendaharaan negeri Patani. Kapalkapal yang datang dari Asia Tenggara kepulauan Nusantara dan Timur Jauh tidak membayar Cukai tetapi diharuskan mematuhi sistem pembelian dengan penjualan sebanyak $25 \%$ muatan kargo dengan harga pasaran potongan sebanyak $20 \%$. Sistem ini menunjukan ciri perdagangan yang tipikal sebagai tempat perdagangan antar bangsa. ${ }^{56}$

Patani juga menerima barangbarang impor ${ }^{57}$ dari luar daerah, seperti

\footnotetext{
53 Merupakan Sultan Pahang ke XII dan merupakan Sultan Pahang yang terakhir 15921614

54 Phra Nang cao Yang adalah gelaran yang diberikan oleh Raja Siam terhadap Raja di Patani yang Artinya adalah raja Perempuan, sebelumnya Raja Hijau dan Raja Biru menerima gelar tersebut, tetapi Raja Ungu menolak pemeberian gelar tersebut.

Haji Abdul Halim Bahsah ( Abhar), Raja Campa dan Dinasti Jembal dalam Patani Besar Patani, Kelantan dan Terengganu hal 100

${ }^{56}$ Ibid hal 23

${ }^{57}$ Lihat Lampiran 10
}

beras., seperti juga sagu, ubi-ubian, dan gandum. Sekitar abad 15 beras sudah menjadi favorit di Asia Tenggara dan dapat tumbuh dengan baik. Patani merupakan wilayah pengimpor beras dari Siam dan Kamboja. ${ }^{58}$ Dan barang lainnya adalah perhiasan merupakan barang yang utama setelah pakaian. Perhiasan emas biasanya dicari sebagai suatu cara untuk menabung atau simbol kekayaan atau status dari seseorang. Emas yang sangat murni dan lunak digunakan untuk tujuan mudah dibentuk, dipotong atau dijual kembali, dan secara keseluruhan kawasan di Asia Tenggara kaya akan emas. 59

\section{B. Saluran Islamisasi Masa Raja Ungu Melalui Politik}

Sistem politik yang dianut Asia Tenggara pada umumnya sangat dipengaruhi oleh China dan India Kuno, seperti kebudayaan yang besar di India dan China masyarakat di Asia Tenggara juga awalnya berkelompok dan bersukusuku. Timbulnya kebudayaan di suatu wilayah salah satunya di tentukan oleh faktor geografis. Wilayah semenanjung yang letaknya geografis merupakan jalur perdagangan antara India dan China oleh sebab itu banyak timbul kerajaan seperti Funan, Sriwijaya, Majapahit dan Malaka. $^{60}$

Masuknya Islam di Patani menyebabkan sistem pemerintahan yang semula sistem kerajaan berubah menjadi sistem khalifah dengan berpegang pada hukum Islam. Patani juga memiliki hierarki otoritas keagamaan berdasarkan hukum Islam (Syariah). Sultan memliki mufti sebagai konselor utama agama. Mufti adalah pejabat tertinggi negara

\footnotetext{
58 Anthony Reid. Asia Tenggara Dalam Kurun Niaga 1450-1680 hal 24-26

${ }^{59}$ Ibid hal 110

60 Yong Mun Cheong (Ed). Eksplorasi Sejarah India, Asia Tenggara Cina. (Federal Pubilcation: Singapura, 1999) hal 62-73
} 
dalam mengeluarkan fatwa dan interpretasi Al-Quran dan memiliki kewenangan mengkritisi sultan jika sultan keluar dari syariah. Di bawah mufti terdapat seorang kadi, sebagai hakim Islam dan penasehat keagamaan kepada bupati, imam khatib dan bilal. ${ }^{61}$ Kuatnya Islam di Patani dalam bidang politik dan ekonomi membuat banyak hubungan dengan wilayah-wilayah lain.

Di tingkat pusat, pembesar memegang jabatan-jabatan sebagai bendahara. Bendahara diangkat untuk membantu sultan dalam menjalankan pemerintahan. Dalam struktur pemerintahan kesultanan Patani, sultan mempunyai kekuasaan yang mutlak. Sultan memerintah berdasarkan adat Temenggung dan hukum Islam. Struktur pemerintahan Patani merupakan warisan sistem politik Melayu tradisional. Sultan merupakan penguasa tertinggi di Patani dalam menjalankan roda pemerintahan. ${ }^{62}$

Setiap daerah atau kabupaten, terdapat pangeran atau wakil yang menggantikan sebagai penguasa lokal, yang bertanggung jawab terhadap keputusan penting seperti deklarasi perang dan menandatangani perjanjian. Di tingkat kota, terdapat pejabat keliling dari kerajaan di bawah perintah sultan dan pangeran serta terdapat pejabat daerah di daerah-daerah. Dalam perekonomian terdapat shah bandar yang mengelola pasar, gudang, dan keperluan perdagangan. ${ }^{63}$

Sultan Ismail Syah meninggal pada tahun 1530 yang telah menduduki tahta Patani selama 30 tahun. Sultan

61 Abdurahman dawud sejarah negara Patani Darussalam, Yala dalam bahasa Jawi hal 15, dalam skripsi Proses Integrasi Patani Ke dalam Teoriti Thailand 1902-1932.

62 Kerajaan Melayu Tradisional dalam www.scribd.com

${ }^{63}$ Abdurahman Dawud sejarah negara Patani Darussalam, Yala dalam bahasa Jawi hal 15, dalam skripsi Proses Integrasi Patani Ke dalam Teoriti Thailand 1902-1932.
Ismail Syah meninggalkan tiga orang anak yaitu Sultan Muzaffar Syah, sultan Mansyur Syah dan Raja Aisyah. Setelah Sultan Ismail Syah tiada, digantikan oleh anaknya Sultan Muzaffar Syah. Setelah cukup makmur dalam bidang ekonomi dan Politik maka Sultan Muzaffar Syah mencoba menjalin hubungan diplomatik dengan beberapa negara, antara lain dengan Siam, Siam merupakan suatu kekuatan besar yang berkuasa di semenanjung utara, dan Patani sudah diklaim di bawah naungan Siam sejak kerajaan Sukhothai ${ }^{64}$.

Sekitar tahun 1550 Burma menyerang Siam, yang sejak awal telah mengklaim Patani di bawah naungannya maka mereka meminta bantuan kepada Patani untuk membantu peperangan yang terjadi antara Siam dan Burma, Patani mengirim pasukan yang didalamnya terdapat Sultan Muzaffar Syah dan Sultan Mansur Syah. Tujuan pasukan datang ke dalam peperangan adalah untuk membantu Siam namun, kenyataannya pasukan Patani malah menyerang Siam. Serangan ke atas Siam ini menjadi awal bagi permusuhan Siam dan Patani hingga saat ini, penjajahan yang terus berlangsung mengakibatkan kerugian besar yang diterima oleh rakyat Patani.

Gugurnya Sultan Muzaffar Syah dalam pertempuran menyebabkan Patani dipimpin oleh sang adik, Sultan Mansyur syah. ${ }^{65}$ Sultan Mansyur Syah merasa perlu adanya perbaikan hubungan dengan Kerajaan Ayuthia. Maka dipersiapkan utusan dalam mencairkan hubungan di antara Siam

\footnotetext{
64 Kerajaan Sukhothai adalah kerajan yang didirikan oleh orang-orang Siam, setelah jatuhnya kerajaan Sukhothai maka digantikan oleh kerajaan Ayuthia sampai akhirnya pusat pemerintahan Siam berada di tangan Dinasti Bangkok.

${ }^{65}$ Mohd Zamberi A Malek. Umat Islam Patani Sejarah dan politik. hal 34-39
} 
dan Patani. Sepulangnya utusan yang datang ke Siam, kabar baik yang diterima oleh Sultan Mansyur Syah. Sultan Mansyur Syah hanya memerintah sekitar delapan tahun 1564-1572.

Setelah wafatnya Sultan Mansyur Syah, maka yang berhak menaiki tahta kerajaan, sesuai dengan wasiat beliau adalah anak dari Sultan Muzaffar Syah yaitu Raja Bambang (anak Gundik) dan sultan Patik Siam yang saat itu berusia 9 tahun. Dalam peraturan istana dikatakan bahwa anak dari Gundik ${ }^{66}$ tidak dapat menaiki tahta maka dengan adanya aturan tersebut Sultan Patek Siam dilantik menjadi raja meskipun usianya masih 9 tahun. Kelangsungan pemerintahan yang dipimpin oleh Patek Siam tidak bertahan lama karena Raja Bambang kakak dari Patek Siam iri dan tidak suka melihat adiknya menjadi raja. Percobaan pembunuhan pun dilakukan oleh Raja Bambang dan dibantu oleh Seri Amarat. Hasil dari rencana pembunuhan ini telah memakan korban yaitu Patek Siam, Raja Aisyah dan Raja Bambang Sendiri.

Peristiwa di Patani yang diperintah oleh anak yang berusia sepuluh tahun terulang kembali. Patek Siam wafat pada 1573 maka Sultan Bahadur Syah diangkat menjadi raja Patani, Sultan Bahadur syah adalah anak dari Sultan Mansyur Syah. Anak-anak Mansyur Syah yang lain adalah Raja Hijau, Raja Biru, Raja Ungu, Raja Emas Kerenceng dan laki-laki Raja Bima (anak Gundik). Anak Sultan Mansyur Syah yang lain tidak bisa menaiki tahta karena mereka perempuan dan Raja Bima adalah anak dari Gundik.

Peristiwa pembunuhan yang terjadi di dalam Istana Patani pada masa pemerintahan sultan Patek Siam terulang kembali pada masa Sultan Bahadur syah,

66 Sebutan bagi perempuan simpanan raja atau sering dikenal dengan istilah selir.
Raja Bima saudara dari Sultan Bahadur merasa iri dan membunuh Sultan Bahadur Syah yang dibantu Oleh Seri Amar Pahlawan. Dengan peristiwa ini maka perempuan-perempuan menaiki tahta kerajaan dan mencapai masa keemasan pada pemerintahan raja-raja perempuan. $^{67}$

Wafatnya Sultan Bahadur Syah pada tahun 1584 maka terjadi kebimbangan di kalangan kerajaan, karena menurut undang-undang yang berlaku yang mengikuti sistem pemerintahan Melayu yang dapat diangkat menjadi raja adalah kerabat dekat laki-laki dari raja atau anak lakilaki raja, sedangkan di Patani Raja Mansyur Syah meninggalkan anak-anak Perempuan, Raja Hijau, Raja Biru, Raja Ungu dan Raja Emas Kerenceng ( Meninggal Saat Usianya 5 Tahun).

Perundingan pun terjadi dikalangan Istana maka Raja Hijau anak sulung dari Sultan Mansyur Syah dilantik menjadi Raja Patani tahun 1584, masa pemerintahan Raja Hijau cukup lama sekitar 32 tahun. Kenaikan tahta Raja Hijau tidak didukung sepenuhnya oleh rakyat, banyak pihak yang tidak setuju dengan kenaikan Raja Hijau, maka dari itu terdapat pemberontakan yang dilakukan oleh Bendahara ${ }^{68}$ Kayu Selat beserta pengikut dari Sai diikuti oleh 5000 orang.

Masa pemerintahan Raja Hijau terbilang aman dan penuh kemakmuran, namun pada masa ini telah terjadi percobaan penyerangan terhadap Patani yang dilakukan oleh Raja Siam Naresuan pada tahun 1603. Armada Siam yang dipimpin oleh Opya Deca ini gagal dalam menyerang Patani dikarenakan kesiapan dari orang-orang Melayu Patani. Selain itu, rakyat Patani sudah dapat menggunakan senjata api yang

\footnotetext{
67 Ahmad Fathy Al-Fatani. Pengantar Sejarah Patani. hal 20

${ }^{68}$ Bendahara adalah perdana menteri
} 
diperkenalkan oleh para pedagang dari Eropa. $^{69}$

Di masa Raja Biru, ia rajin mengadakan kunjungan ke Kelantan untuk menjalin hubungan, akhirnya di tahun 1619 negeri Patani dan Kelantan digabungkan, ${ }^{70}$ Penggabungan ini terjadi cukup lama sekitar 131 tahun . Dalam mengukuhkan pertahanan kerajaan Patani pada masa Raja Biru dibuat meriam untuk digunakan dalam perang, meriam tersebut adalah Seri Patani, Seri Nagari dan Seri Mahalela. Meriammeriam tersebut di letakan di benteng pertahanan Patani sehingga jika ada musuh yang menyerang langsung dapat digunakan. Patani merupakan Kerajaan yang gemilang baik dalam hal perdagangan, perpolitikan hingga pusat penyebaran Islam. Namun hal itu tidak bertahan lama akibat serangan dari Siam, Patani akhirnya jatuh ke tangan Siam pada tahun 1785 dan berbagai meriam tersebut dirampas oleh Siam. Hingga saat ini meriam tersebut masih ada dan diletakan di depan Gedung Kementrian Pertahanan yang dijadikan sebagai Tugu kemenangan. ${ }^{71}$

Setelah pemerintahan Raja Biru yang relatif aman dan damai, Raja Ungu yang memerintah Patani tidak lama, namun pada masanya sempat menyeret Patani kepada peperangan dengan Siam. Walapun beberapa serangan telah dilakukan oleh Siam, Patani masih bertahan hingga jatuhnya Patani tahun 1785. Kestabilan Patani menjadikan Patani sebagai kerajaan yang kuat dan dihormati oleh negeri-negeri Jiran termasuk Ayuthia sendiri. ${ }^{72}$

Pada masa Kerajaan Sukhothai dan Ayuthia, Patani dianggap berada di

69 Mohd Zamberi A Malek. Umat Islam Patani Sejarah dan Politik. hal 50

${ }^{70}$ Lihat Lampiran 11

${ }^{71}$ Lihat lampiran 12

72 Nik Anwar nik Mahmud. Sejarah Perjuangan Melayu Patani 1785-1954. hal 18 bawah naungan kerajaan Siam. Masa pemerintahannya organisaikan ke dalam admisnistrasi militer dan sistem pemerintahan pusat. Dibawah administrasi sipil terdapat departemen pemerintahan lokal yang mengontrol kota-kota dan propinsi dan amdministrasi militer memiliki peraturan dimana para pemuda harus wajib militer. $^{73}$

Namun, pemerintahan Siam mendapat sedikit kesulitan dalam menegaskan pengendalian atas negaranegara yang berada di bawah naungannya. Hal ini disebabkan karena jarak dari ibu kota kepada negara-negara Melayu terlalu jauh untuk memungkinkan integrasi yang sebenarnya ke Ayuthia. ${ }^{74}$ Menurut Nik Anwar Nik Mahmud, kedudukan Patani yang bersebelahan

dengan Siam menjadikan hubungan kedua negeri agak istimewa. Kedua negeri ini saling bekerjasama dalam hal perdagangan, saling mengirimkan utusan, namun negeri ini saling menyerang dan menjadi musuh walaupun dalam sejarahnya Patani yang pertama kali menyerang Ayuthia namun Ayuthia yang lebih sering menyerang Patani.

Pengklaiman negeri Patani di bawah naungan Siam dibuktikan dengan prasasti yang ditemukan di Nakhorn Sri Tammarat atau Ligor yang merupakan prasasti Raja Ram Khamhaeng (12831337). Raja Ram Khamhaeng mengadakan ekspedisi ke selatan semenanjung dan menaklukan kerajaankerajaan Melayu seperti Langkasuka. Namun, beberapa sarjana juga

\footnotetext{
${ }^{73}$ Yong Mun Cheong (Ed). Eksplorasi Sejarah India, Asia Tenggara dan China. (Federal Publication: Singapura. 1999) hal 75

74 Howard Federspiel M. 2007. Sultans, shamans, and saints : Islam and Muslims in Southeast Asia. (University of Hawai'i Press: USA). Hal 27
} 
meragukan prasasti tersebut dengan mengatakan bahwa itu hanyalah pernyataan saja yang bertujuan mengagung-agungkan kerajaan Ram Khamhaeng . ${ }^{75}$

Beberapa faktor yang menyebabkan pertahanan Patani begitu kuat dari serangan Siam. Negeri Patani memiliki sungai yang menghubungkan darat dan lautan, sungai tersebut sempit dan jika ada kapal musuh yang masuk melalui sungai maka kapal akan berjalan dengan lambat dan hal ini dapat dimanfaatkan oleh tentara Patani untuk menembakkan meriam dan senapan. Pada bagian pantai di Patani terdapat pula sebuah benteng, terletak di arah barat laut ibukota dan terletak di arah timur laut ibukota. Sedangkan di sebelah timur Patani terdapat benteng yang kokoh yang tebal yang dikenal dengan nama benteng Raja Biru. ${ }^{76}$ Untuk lebih mempertahankan negeri Patani, maka Raja Ungu bekerja sama dengan tentara Portugis.

Dalam peperangan antara Siam dan Patani, sebelumnya Raja Ungu telah mengatur strategi dalam peperangan. Strategi yang dilakukan Raja Ungu adalah mengutus tentara Patani untuk meyerang Pathalung yang berdekatan dengan Ligor. Alasannya adalah tentara Siam biasanya akan menyerang Patani melalui Ligor. ${ }^{77}$

Siam pun melakukan strategi yang sama dengan Patani, Siam juga bekerja sama dengan tentara asing yaitu tentara Belanda. Strategi Siam untuk menyerang Patani adalah meminta bantuan Belanda yang berpusat di Jakarta. Faktor yang menyebabkan

\footnotetext{
${ }^{75}$ Howard Federspiel M. 2007. Sultans, shamans, and saints : Islam and Muslims in Southeast Asia. (University of Hawai'i Press: USA). Hal 17

76 Ahmad Fathy Al-Fatani. Sejarah Pengantar Patani. hal 24

77 Mohd Zamberi A Malek. Umat Islam Patani Sejarah dan Politik. hal 66
}

Belanda membantu Siam adalah Patani dibantu oleh Portugis, yang latar belakangnya adalah saingan dagang Belanda di Asia Tenggara. Jika Belanda membantu Siam menaklukan Patani, maka Belanda dapat menyingkirkan Portugis dalam persaingan dagang. Selain alasan itu, terdapat dua pedagang VOC dan tujuh orang Jepang yang bekerja pada VOC ditawan di Patani. Hal lain yang membuat hubungan keduanya erat dikarenakan Patani telah mengadakan kerjasama dengan Portugis. Gubernur Jendral VOC mengirim surat kepada Raja Siam untuk memecahkan kerjasama antara tentara Patani-Portugis.

Untuk menjaga hubungan baiknya dengan Siam maka pihak VOC mengirimkan lima buah kapal ke Ayuthia dan dua kapal yang terpisah untuk singgah ke Patani yang dipimpin oleh Antonij Caen untuk membujuk Raja Ungu mengantar utusan ke Siam dalam rangka perdamaian dan juga meminta Raja Ungu untuk membebaskan Kapal orang-orang Siam yang pernah ditawan pihak Patani.

Datangnya utusan dari pihak Belanda tidak diterima dengan baik oleh Raja Ungu. Raja Ungu justru mengirimkan pesan bahwa Raja Siam adalah penjahat, pembunuh, pengkhianat dan tidak berhak mendapatkan kedudukan sebagai raja. Raja yang dimaksud adalah Raja Phrasat Thong. Raja Phrasat Thong menaiki tahta di tahun 1630. Sebelumnya Ayuthia diperintah oleh Raja IntaRaja II namun di tahun 1624 meninggal dunia dan digantikan oleh Raja Jetta 1628-1630 dan kemudian digantikan oleh Raja Atityanong 1630, belum sempat memerintah Raja Atityanong beserta seluruh keluarga dibunuh oleh Raja Phrasat Thong. Akibat perstiwa tersebut, Raja Ungu menolak memberikan upeti seperti para pendahulunya dan menolak mengakui kekuasaan Raja Phrasat Thong 
dan menyatakan diri bahwa Patani bebas dari naungan Siam. ${ }^{78}$

Serangan ke Patani terjadi 1634, persiapan dilakukan dengan sangat baik. Dalam buku Mohd Zamberi A Malek dikatakan 30.000 tentara Siam berkuda dan bergajah disiapkan untuk menyerang Patani dengan gabungan tentara dari Ligor, Singgora dan Pathalung. Perkiraaan jumlah tentara Siam sekitar 60.000 orang. Tentara terbesar yang pernah dikerahkan oleh Siam. ${ }^{79}$

Siam menyerang Patani, saat keadaan Siam sedang tidak stabil. Siam sedang berurusan dengan Burma dan Kamboja yang sering memberikan ancaman terhadap kestabilan politik Siam. Siam tetap bertekad untuk menyerang Patani. Utusan ke Belanda telah dikirim ke Batavia, dan pihak Belanda telah setuju untuk membantu Siam dalam menyerang Patani. Kapal Belanda akan diberangkatkan dengan persenjataan yang lengkap dan akan dipimpin oleh Komandan Class Bruijn.

Patani dibantu oleh 50 buah kapal dari Johor dan Pahang serta 6 kapal dari Portugis berasal dari Malaka. Kubu pertahanan orang-orang Patani dilengkapi dengan benteng yang tebal dan masing-masing sisi diletakkan meriam. Setelah tujuh hari peperangan ternyata jumlah makanan tentara Siam semakin menipis, dan menyebabkan mereka untuk mundur. Saat itu juga tentara Siam menunggu datangnya kapal Belanda yang telah dijanjikan. Mundurnya tentara Siam menandakan kekalahan perang dengan Patani tahun 1634.

Kabar mundurnya tentara Siam dari Patani didengar oleh Raja Siam. Kegagalan dan mundurnya tentara Siam

\footnotetext{
${ }^{78}$ Ibid hal 66

${ }^{79}$ Tentara sebanyak ini hanyalah digunakan untuk menyerang negeri Patani yang jumlah penduduknya lebih sedikit dibandingkan dengan Siam Ibid hal 68
}

ini memalukan mereka terutama kepada pihak raja dan negara Siam. Dan yang lebih memalukan lagi mereka merupakan sebuah angkatan besar tetapi tidak berjaya menundukan sebuah kerajaan kecil terlebih sedang dipimpin oleh seorang raja perempuan. Raja Siam Phrasat Thong terlalu marah sehingga tidak mengijinkan tentaranya masuk kedalam istana sebelum ada laporan yang pasti mengenai hasil peperangan. Raja Phrasat Thong menyalahkan tentara Siam yang terlalu cepat meninggalkan Patani dan tidak menunggu kedatangan kapal Belanda, ${ }^{80}$

Siam juga menyiapkan hukuman bagi Belanda yang telah mengingkari janji dalam membantu Siam. Namun, pihak Belanda berdalih bahwa mereka telat datang karena mereka telah banyak menenggelamkan kapal Patani di lautan. ${ }^{81}$ Angkatan Perang Belanda pimpinan Class Bruijn telah berlayar menuju Patani tetapi angkatan Belanda terlambat datang dan mengetahui bahwa angkatan Perang Siam telah mundur dari Patani. Mengetahui keterlambatan pihak Belanda maka Raja Siam memutuskan hubungan dagang dengan VOC dan memulangkan para pegawainya, pegawai Siam dan Belanda tidak dizinkan untuk berhubungan. Joost Schouten dan Class Bruijn datang ke Ayuthia untuk menerangkan mengapa mereka tidak datang dalam pertempuran antara Patani dan Siam. Dari penjelasan tersebut, Raja Siam dapat menerima dan mereka kembali menjalankan kerjasama.

Siam kalah dalam peperangan maka Siam kembali menyiapkan angkatan yang lebih besar dari sebelumnya. Dari pengalaman kekalahan dulu, Siam menyiapkan lebih dari 100 buah kapal perang juga senjatasenjata dan kapal-kapal yang diimpor

\footnotetext{
${ }^{80}$ Ibid hal 69

${ }^{81}$ Ibid hal 70
} 
dari negeri Jiran. Siam juga meminta pihak Belanda di Jakarta untuk membantu dan diharapkan datang tepat pada waktunya. Namun, pihak Belanda tidak dapat membantu karena situasi politik yang telah berbeda.

Belanda hanya akan mengutus orang untuk bertemu dengan Raja Ungu untuk berunding. Orang itu adalah Anthonij Caen. Perwakilan tersebut ditugaskan untuk membujuk Raja Ungu untuk memutuskan hubungan baiknya dengan Portugis. Caen juga menyuruh Raja Ungu mengantar utusan ke Siam untuk mengadakan perdamaian dan meminta Patani mengembalikan Kapal Siam yang pernah ditawan Patani. Campur tangan juga dilakukan oleh Pihak Kedah pimpinan Sultan Rijaludin Muhamad Syah, ia meminta kepada pihak Siam untuk mengirim utusan ke Patani untuk mendapatkan perdamaian. Sultan Kedah juga menyatakan jika Siam menyerang kembali Patani maka hasilnya akan sama, Siam akan mengalami kekalahan justru semakin parah dari sebelumnya. Akhirnya utusan dari Siam dikirim ke Patani dan meminta Raja Ungu mengirim kembali upeti seperti biasanya sebagai tanda perdamaian dengan Raja Siam. Raja Ungu tetap bersikeras tidak mau mengantar upeti kepada Siam. Atas saran dari Belanda, baru Raja Ungu mengantarkan utusan untuk meminta maaf dan menyambung kembali hubungan diplomatik yang pernah terputus dan juga bersepakat tidak akan meminta ganti rugi akibat perang. ${ }^{82}$

Tahun 1635 Raja Ungu wafat, pada masa pemerintahannya ia dapat menstabilkan Politik patani ke tahap yang membanggakan. Menurut Joost Schouten, pengarah $V O C$ di Ayuhthia, Raja Ungu adalah Raja perempuan yang berani di zamannya. Ia sanggup

\footnotetext{
${ }^{82}$ Ibid hal 72
}

berhadapan dengan penjajah yang besar dan kejayaannya menentang Siam dengan mempertahankan kedaulatan negeri Patani. ${ }^{83}$ Hikayat Patani mengatakan salah satu teknik yang dilakukan oleh tentara Patani adalah mereka menyamar sebagai tentara Siam yang terdiri atas tentara campuran. Mereka menyebabkan bekalan tentara Siam habis. Hal ini dikatakan dalam Buku Haji Abdul Halim Bahsah sebagai teknik perang yang tidak pernah dilakukan di masa itu.

Dalam bidang perdagangan, sebuah serikat perkapalan kerajaan telah didirikan untuk meningkatkan taraf perdagangan dan produksi dalam negeri dalam menstabilkan ekonomi Patani. ${ }^{84}$ Barang-barang ekspor diperdagangkan. Misi perdagangan ini diketuai oleh Nahkoda Sandang yang bergelar saudagar raja, Kapal-kapal perdagangan dikirim ke beberapa tempat dan pelabuhan menjalankan perniagaan dalam persaingan bebas dengan perusahaan-perusahaan perorangan. ${ }^{85} \mathrm{Di}$ sisi lain Patani terus menjadi pusat kegiatan penyebaran agama Islam hingga akhir abad ke 17. Usaha-usaha menyebarkan Islam terus dilakukan, salah satunya dengan mengirim ulama Patani Syekh Abdul Jalil Al-Fatani ke Kalimantan dan wilayah-wilayah sekitarnya. ${ }^{86}$ Patani menjadi pusat institusi yang mempelopori kebudayaan Melayu. $^{87}$

\footnotetext{
${ }^{83}$ Ibid hal 72

${ }^{84}$ Ibid hal 114

85 Mohd Zamberi A Malek. Patani dalam Tamadun Melayu. Hal 24

86 Mohd Zamberi A Malek. Patani dalam Tamadun Melayu. Hal 34

${ }^{87}$ Mohd Zamberi A Malek. Umat Islam Patani Sejarah dan Politik hal 74
} 


\section{PENUTUP}

\section{A. Kesimpulan}

Puncak dari kegemilangan Patani saat Patani dipimpin oleh raja-raja perempuan, bermula dari Raja Hijau, Raja Biru, Raja Ungu dan Raja Kuning. Patani pada abad 17-18 merupakan pelabuhan utama yang penting bagi perdagangan di negeri sekitar, didukung oleh alam yang membuat Patani bertambah ramai di kunjungi. Keadaan ekonomi dan perdagangan yang baik juga didukung oleh kestabilan politik. Patani pada masa pemerintahan Raja Ungu merupakan kekuatan yang tak tergoyahkan, walapun sempat diserang oleh musuh bebuyutan Siam namun karena didukung oleh beberapa hal Patani masih bisa mempertahankan kedaulatannya mulai dari kerajaan Patani terbentuk di abad ke 15 hingga akhirnya jatuh ke tangan Siam 1785.

Beberapa faktor yang

menyebabkan perdagangan Patani dengan negeri-negeri lain begitu maju dan pertahanan Patani begitu kuat dari serangan Siam:

1 Negeri Patani memiliki alam yang luar biasa dan strategis yang memungkinkan para pedagang dan pelancong yang membawa kapal tidak khawatir kapalnya akan terkena hempasan ombak. Pelabuhan Patani sebagai tempat yang cocok dalam singgahan kapal-kapal jika terdapat angin muson timur laut. Selain itu, Patani memiliki sumber daya alam yang mencukupi seperti rempah-rempah, tempat pertemuan antara pedagang barat dan Cina, Jepang, kestabilan politik pemerintahan Patani serta kemudahan seperti sistem cukai.

2. Negeri Patani memiliki sungai yang menghubungkan darat dan lautan, sungai tersebut sempit dan jika kapal musuh yang masuk melalui kapal tersebut maka kapal tersebut berjalan dengan lambat dan dapat dimanfaatkan oleh Patani dengan menembakan meriam dan senapan. Pada bagian pantai di Patani terdapat pula sebuah benteng, terletak di arah barat laut ibukota dan terletak di arah timur laut ibukota. Strategi Perang yang diterapkan memiliki keungggulan yang luar biasa yang terjadi di zaman itu, peralatan perang yang lengkap memberikan keuntungan tersendiri, seperti dibuatnya meriam-meriam dan juga benteng pertahanan, kerjasama dengan negeri lain juga merupakan faktor yang sangat mendukung seperti dengan tentara Portugis, Johor dan Pahang.

\section{B. Saran}

Saran yang diajukan oleh penulis kepada para penulis lain, bahwa hendaknya menuliskan tentang sejarah yang lebih terpinggirkan, bukan menulis sejarah yang sudah terkenal dan memang mendapat tempat yang khusus dalam pemerintahan setempat. Seperti tulisan ini mengharapkan agar bahasan tentang pemerintahan perempuan yang berkuasa dan mencapai zaman keemasan lebih diperhatikan, terkadang penulisan sejarah perempuan terpengaruh oleh budaya yang sedang berkembang, sistem dalam pandangan budaya patriaki perempuan dianggap sebagai second class yang selalu berada di bawah lakilaki, tetapi masa raja perempuan Patani hal ini tidak terbukti.

Kemudian diharapkan bagi para pembaca khususnya masyarakat Patani memahami betul sejarah masa lampau mereka, dengan memahami sejarah, rakyat Patani dapat berjuang mempertahankan kedaulantan mereka 
dan melihat bahwa Patani pernah berjaya dalam bidang perdagangan, perpolitikan yang menyebabkan Patani mencapai masa keemasannya, dengan mempelajari sejarah Patani dapat kembali merenggut kembali kejayaannya sama seperti abad sebelumnya. Perjuangan ini tentu saja tidak dapat diraih sendiri, membutuhkan publikasi luas untuk mengenalkan Patani pada dunia.

\section{Daftar Pustaka}

\section{Sumber Primer}

Binci, Arifin dkk. Patani Darussalam. Yala: Center Of Southern Thai Islamic Culture. 2000.

Fatani, Ahmad Fathy. Pengantar Sejarah Patani. Kedah: Pustaka Darussalam. 1994.

Syukri, Ibrahim. Sejarah KeRajaan Melayu Patani. Malaysia: UKM. 2002.

Teeuw, A dan Wyaat. Hikayat Patani. Jakarta: KITLV. 1970

\section{Sumber Sekunder}

Abd. Jalil Bin Borhan. Sejarah Islam ke Nusantara. Jakarta: STPM.

Abdullah, Taufik. Ensiklopedi Tematis Dunia Islam. Jakarta: PT Ichtiar Baru Van Hoeve. 2002.

Abdullah, Taufik. Islam di Asia Tenggara Persfektif Kontemporer. Jakarta : LP3ES. 1990

Abdurrahman, Dudung. Metode Penelitian Sejarah. Jakarta: Logos. 1999.

Al-Habib Alwi bin Thahir Al-Hadad. Masuknya Islam di Timur Jauh. Jakarta: Lentera. 2001.

Bashah, Haji Abdul Halim. Raja Campa dan Dinasti Jembal dalam Patani Besar, Patani, Kelantan dan Terengganu.
Kelantan : Pustaka Reka. 1994.

$$
\begin{aligned}
& \text { Bongas, Wayne A. Islamic } \\
& \text { Cemeteries in Patani . } \\
& \text { Kulala Lumpur: The } \\
& \text { Malaysian Historical. 1988. }
\end{aligned}
$$

Cheong , Yong Mun (Ed).
Eksplorasi Sejarah India,
Asia Tenggara dan China.
Singapura:
Publication. 1999.

Federspiel, Howard M. Sultans, shamans, and saints : Islam and Muslims in Southeast Asia. USA: University of Hawai'i Press. 2007.

Forbes, Andrew Dw. The Muslim of Thailand vol 2 politic of the Malay. Road Gaya India: Speaking South East Asian. Sagar, Ram. Center For South East Asian Studies. 1989.

Gombrich, Richard F. Theravada Buddhism A social history from ancient Benares to modern Colombo Second edition. New York: Taylor \& Francis e-Library. 2006.

Gottschalk, Louis. Mengerti Sejarah, terj. Nugroho Notosusanto. Jakarta: UI Press. 1986.

Hall, DGE. Sejarah Asia Tenggara. Surabaya: Usaha Nasional. 1988.

Hasbullah, Moeflich (Ed). Asia Tenggara konsentrasi Baru Kebangkitan Islam. Bandung: Fokusmedia. 2003. Hasjmy, A. Sejarah Masuk dan Berkembangnya Islam di Indonesia. Aceh: Offset. 1993.

Kartodirdjo, Sartono. Pendekatan Ilmu Sosial Dalam Metode Penelitian Sejarah. Jakarta: PT. Gramedia Pustaka Utama. 1992. 
Kettani, M. Ali. Minoritas Muslim di Dunia Dewasa Ini, Terj. Zarkowi Soejoeti. Jakarta: PT Raja Grafindo Persada. 2005.

Lapidus, Ira M. Sejarah Sosial Umat Islam. Jakarta: PT. Raja Grafindo Persada. 1999.

Malek, Mohd Zamberi A. Patani dalam Tamadun Melayu. Kuala Lumpur: Dewan Bahasa dan Pustaka Kementrian Pendidikan Malaysia. 1994.

Malek, Mohd Zamberi A. Umat Islam Patani Sejarah dan Politik. Kelantan: Hisbi Shah Alam. 1993.

Man. Wk Che. Muslim Seperatism The Moros of Southern filipines and the Malays of Southern Thailand. New York: Singapore Oxford University Press. 1990.

Mubarok, Jaih. Sejarah Peradaban Islam. Bandung: Pustaka Bani Quraisy. 2004.

Mujani, Wan Kamal. Minoritas Muslim Cabaran dan Harapan Menjelang Abad 21. Bangi: Fakulti Pengajian Islam-Universiti Kebangsaan Malaysia. 2002.

Nik anuar Nik Mahmud. Sejarah Perjuangan Melayu Patani. 1785-1954. Malaysia: University Kebangsaan Malaysia. 1999.

Nurdi, Herry. Perjuangan Muslim Patani. Jakarta: Sabili. 2010.

Nasuhi, Hamid. Dkk. Pedoman Penulisan Karya Ilmiah (skripsi, Tesis dan Disertasi). Jakarta: Ceqda. 2007

Piter, Gowing. "Moro dan Khek: Kedudukan Minoritas Muslim di Filipina dan Thailand" dalam Islam di
Asia

Perkembangan

Kontemporer. Tenggara

LP3ES. 1990.

Pitsuwan, Surin. Islam di Muanghtai Nasionalisme Melayu

Masyarakat Patani. Jakarta: LP3ES. Terjemahan Islam and Malay Nationalism: A Case Study Of The Malay Muslim of Southern Thailand. 1985.

Poesponegoro, Marwati Djoened. Sejarah Nasional Indonesia III. Jakarta: Balai Pustaka. 1993.

Reid, Anthony. Asia Tenggara Dalam Kurun Niaga 14501680. Jakarta: Yayasan Obor Indonesia. 1992.

Reid. Anthony. Sejarah Moderen Awal Asia Tenggara. Jakarta: LP3ES. 2004.

Ricklefs, MC. Sejarah Moderen Indonesia 1200-2008. Jakarta: Serambi. 2009.

Siddique, Sharon dan Abdullah, Taufik. Tradisi dan Kebangkitan Islam di Asia Tenggara. Jakarta: LP3ES. 1989.

\section{Skripsi}

Gerakan Muslim Melayu Thailand Selatan 1973-1980 (Gerakan Miniritas melawan Mayoritas). 2010. Usaman Bueto. Fakultas Adab UIN Sunan Kalijaga Jogyakarta.

Proses Integrasi Patani ke dalam Teoriti Thailand. 2010. Wilda Darnela. Fakultas Abad dan Humaniora UIN Syarif Hidayatullah Jakarta. 